\section{Tetraploid Bell Pepper Shows High In Vitro Pollen Germination at $15{ }^{\circ} \mathrm{C}$}

\author{
Keiko Ishikawa ${ }^{1}$, Hitoshi Kuboki, and Keiichiro Mishiba \\ Plant Cell Technology Laboratory, Faculty of Horticulture, Chiba University, \\ 648, Matsudo, Matsudo-shi, Chiba, 271-8510 Japan
}

\section{Osamu Nunomura \\ Nihon Horticultural Production Institute, 207 Kamishiki, Matsudo-shi, Chiba, 207-2221 Japan}

Additional index words. colchicine, flow cytometry, polyploidy

In Capsicum, the normal development of pollen grains was disturbed at low temperature, inducing seedless fruits, which were deformed in size and shape (Polowick and Sawhney, 1985). Mercado et al. (1997) reported that exine developed at low temperature was thinner than that developed at optimum temperature. However, polyploids are generally characterized to have large flowers and pollen grains (Watts, 1980). We hypothesized that the pollen grains of tetraploid pepper, compared with diploid, would be larger with thicker exine, and that the viability of the pollen at low temperature would be higher. Based on this hypothesis, we tested tetraploid plants of pepper and investigated the rates of pollen germination at low temperature.

Tetraploid plants of Capsicum annuum L. 'Chigusa' (Nihon Horticultural Production Institute) were obtained by colchicine treatment of seeds (Ishikawa et al., 1997). Flow cytometric analysis (Partec PA flow cytometer, Partec, Munster, Germany) showed that $\approx 20 \%$ of the seeds treated with colchicine were tetraploid, comparable with our previous report (Ishikawa et al., 1997).

The tetraploid plants had larger flowers than did plants of the diploid counterpart.

Received for publication 11 Oct. 2000. Accepted for publication 31 May 2001. We thank T. Koba and R.P. Umali for their critical review of the manuscript and their suggestions.

${ }^{1}$ E-mail address: ishikawa@midori.h.chiba-u.ac.jp
While diploid flowers typically had six petals and stamens, tetraploid flowers typically had seven petals and stamens. Tetraploid plants had 20\% larger ovaries and 25\% larger diameter pollen grains than diploids.

In order to investigate in vitro germination rates of the pollen, flower buds were excised one day before anthesis and incubated at $25^{\circ} \mathrm{C}$ in petri dishes with wet filter papers. After $24 \mathrm{~h}$, pollen grains were put into $50 \mu \mathrm{L}$ of liquid Brewbaker and Kwack's medium $\left(100 \mathrm{mg} \cdot \mathrm{L}^{-1}\right.$ boric acid; $300 \mathrm{mg} \cdot \mathrm{L}^{-1}$ calcium nitrate; $200 \mathrm{mg} \cdot \mathrm{L}^{1}$ magnesium nitrate; $100 \mathrm{mg} \cdot \mathrm{L}^{-1}$ potassium nitrate and $50 \mathrm{~g} \cdot \mathrm{L}^{-1}$ sucrose, Brewbaker and Kwack, 1963). After $5 \mathrm{~h}$ incubation at $10,15,20,25$, and $30^{\circ} \mathrm{C}$, the pollen grains were observed under a microscope $(\times 100$, Olympus IX70, Japan $)$ and were scored as germinated when the pollen tubes had elongated equivalent to the diameter of the pollen grains.

The mean rates of in vitro pollen germination of diploid 'Chigusa' at 20,25 , and $30^{\circ} \mathrm{C}$ at different temperatures. were $27.4 \%$ to $36.3 \%$ (Table 1) and agreed with reports by Kato (1989) and Mercado et al. (1994). The germination rate was reduced to $6.5 \%$ at $15^{\circ} \mathrm{C}$, reflecting the high sterility level observed in diploid 'Chigusa' at low temperatures. However, the pollen germination rate $(22.1 \%)$ of the tetraploid plants at $15{ }^{\circ} \mathrm{C}$ was significantly $(P<0.05)$ higher than that of the diploid plants. There was no significant difference among the pollen germination rates of diploid plants at 20,25, and $30{ }^{\circ} \mathrm{C}$, nor among those of tetraploid plants at $15,20,25$, and $30^{\circ} \mathrm{C}$ (by Tukey, $P<0.05)$.

\section{Literature Cited}

Brewbaker, J.L. and B.H. Kwack. 1963. The essential role of calcium ion in pollen germination and pollen tube growth. Amer. J. Bot. 50:859-865.

Ishikawa, K., K. Mishiba, H. Yoshida, and O. Nunomura. 1997. Establishment of tetraploid plants of Capsicum annuиm L. by colchicine treatment with the analysis of flow cytometry. Capsicum and Eggplant Nwsltr. 16:44-47.

Kato, K. 1989. Flowering and fertility of forced green peppers at low temperatures. J. Jpn. Soc. Hort. Sci. 58:113-121.

Mercado, J.A., R. Fernandes-Muñoz, and M.A. Quesada. 1994. In vitro germination of pepper pollen in liquid medium. Scientia Hort. 57:273281.

Mercado, J.A., M. Martrigo, M.S. Reid, V. Valpuesta, and M.A. Quesada. 1997. Effects of low temperature on pepper pollen morphology and fertility: Evidence of cold induced exine alterations. J. Hort. Sci. 72:17-326.

Polowick, P.L. and V.K. Sawhney. 1985. Temperature effects on male fertility and flower and fruit development in Capsicum anпиит L. Scientia Hort. 25:117-127.

Watts, L. 1980. Polyploidy, p. 22. In: L. Watts (ed.). Flower and vegetable plant breeding. Grower Books, London.

Table 1. In vitro pollen germination rates ${ }^{2}$ of diploid and tetraploid plants of Capsicum annuum 'Chigusa'

\begin{tabular}{lccccc}
\hline \hline & \multicolumn{5}{c}{ Temperature $\left({ }^{\circ} \mathrm{C}\right)$} \\
\cline { 2 - 6 } Plants & 10 & 15 & 20 & 25 & 30 \\
\hline Diploid & $0.1 \pm 0.1$ & $6.5 \pm 2.2$ & $27.4 \pm 2.9$ & $36.3 \pm 6.4$ & $29.6 \pm 5.3$ \\
Tetraploid & $1.4 \pm 0.4$ & $22.2 \pm 2.2^{* * *}$ & $31.3 \pm 3.1$ & $21.9 \pm 2.4$ & $19.5 \pm 2.6$ \\
\hline
\end{tabular}

${ }^{2}$ Germination rates $=($ number of germinated pollen grains $/$ number observed $) \times 100$. The experiments were performed two times using separate preparations of tetraploid plants with comparable results. Data show one set of results. Values represent means \pm SD $(n=6$ to 19).

*** Significant within columns by Tukey's Studentized range test $(P<0.05)$. 